\title{
The Influence of Drill Exercise and Eye Coordination Foot Methods Toward the Smash Skill of Badminton
}

\author{
Andi Taufan Bayu Dewantara Alsaudi \\ The Program of Sport Education, Graduate Program, \\ Jakarta State University, \\ Jakarta, Indonesia \\ anditaufan16.at@gmail.com
}

\begin{abstract}
Focus on the primary concern in the game of badminton is the smash skill, in this case it is the skill in doing the smash badminton. As for the training method used is a method of exercise drill. Based on the study of the problems to be studied and a goal to be achieved, then the form used in this study is a form of experimentation. As for the design that will be used is the design of a factorial design $2 \times 3$. As for the sample in this study was obtained from the number of the reachable population, namely students who have attended courses badminton as much as two classes totalling 70 students. Based on the results of the data, $34.33 \%$ or 10 people obtained scores of badminton smash skills training for students who were trained with drill exercises above the average, $16.66 \%$ or as many as five people were on average, and $49.99 \%$ or as many as fifteen people are below average. Then obtained $\mathbf{2 6 . 6 6 \%}$ or as many as eight people who obtained the score of the results of badminton smash skills training for groups of high ankle coordination students who were trained with drill training methods above the average, $\mathbf{6 . 6 6 \%}$ or as many as two people were on average, and $33.33 \%$ or as many as five people are below the average. Overall, there are significant differences from the results of the skills training smash badminton between a group of students who trained with the method of exercise drill low and high. The results of the skills training smash badminton for a group of students who have eye coordination foot high who trained with the method of exercise drill is better compared with the group of students who have eye coordination foot low which is trained by the method of exercise drill.
\end{abstract}

Keywords: smash, the drill, eye coordination foot, experiment

\section{INTRODUCTION}

Sports achievements are the most popular in Indonesia, one of which is badminton or commonly referred to as badminton. Badminton much-loved by the people of Indonesia, it can be seen by the many enthusiastic people in the participation of any sports activities badminton be held, be it in a match of small and large or international level. Sport badminton is a competitive sport that requires physical readiness, technique, tactics, mental, and maturity champion. The important components that determine the success of a player to excel is the freshness of the body. Have the skills techniques and tactics that better players will not successfully obtain the achievements without having the physical freshness of the prime.

Badminton requires a variety of abilities and skills of complex motion. Badminton also includes competitive sports that require movement of the explosive, much movement to run fast, stop suddenly and then immediately move again, jump to smash, twist the body quickly, reflexes, speed change direction, do a wide step without ever losing the balance of the body. Badminton players should be able to master the basic techniques of playing badminton, such as: the attitude of the stand (stance), the technique of holding the racket, the technique of hitting the ball, and the technique of steps (footwork). Besides it also a badminton player should have the ability to jump to the top (vertical jump) with good so that the player can perform jumping smash better.

Coaching and training of badminton players in Indonesia very much, one of them is through extracurricular activities conducted in schools. The presence of extracurricular activities badminton in school can help develop the skills of the players. One of the factors that support the level of an accomplishment of sports is explosive power the muscles of the limbs, which can be trained through the program a workout. In the game of badminton, explosive power the muscles of the limbs plays an important role in the ability of jump to do the punch smash, drop, and lob more quickly and accurately. To be able to jump higher when performing a jumping smash, a badminton player requires explosive power (power in propelling the muscle while doing exercise. To obtain strong power need to have a good physical programme. The give physical exercise for the gain leg muscle a strong power is Pliometrik. The form of exercise in Pliometrik tools is to enhance leg muscle power, namely: the squat jump and knee tuck jump. All the given exercise program serve to maintain and enhance the muscle strength of the limbs.

Mastery of the basic techniques of badminton that is one of coaching at the College level. Play badminton with both the necessary basic skills to play badminton better. Basic skills in translation include how to hold the racket, how to serve, how to blow up a lob, how to punch down, how to step, how to hit a forehand and how to hit a backhand. See the game of badminton that requires time long enough, the game is fast, agility is very good, as well as conditions that are always explosive, then the game of badminton requires high durability, ability power, and explosive power which is good. Explosive power is the ability of the muscles to exert maximum force in a rapid time [1]. Skills smash the sharp and deadly is required to be owned by each player of badminton not just in a single game but also in the double game. Special double player this skill can not be bargained again this is to be owned by each player to reduce your opponent to get the numbers as much as possible. In this case 
in line with the opinion of reference [2] who said that smash is a very important point in deadly opponent on the pitch.

The smash skill is a skill that most main to end a rally in a badminton game, therefore to achieve maximum performance, the player should own absolute smash skill. A need to be studied that in the game of basic badminton skills is very necessary so that in the next match of badminton players do not feel stiff and stress during the match. The game of badminton in addition to being a place to compete, is also one of the subjects that must be followed by every student in order to meet the provisions of the curriculum in physical education.

Such is the case experienced by students of Education High School Sports Teacher training and Education Science (POR STKIP) Kusuma Negara. STKIP Kusuma Negara is one of the private College in East Jakarta which is located in Cijantung. In the Campus there is a Department of Sport Education (POR) in the college are required to take courses in badminton. During this time the game badminton is one game that is quite favoured by students who follow such courses. His spirit can be seen from the activeness to follow the game of badminton in any extracurricular activities at their school each evening.

Regardless of the study in a theoretical and empiric above in relation to supporting the academic achievement of students in the Department, education Sports which have the characteristics of the subjects charged the practices and theory as well as the less moved the concept of selfunderstanding in each course will affect the way the students against him, and will affect the achievement. By looking at the importance of motivation in the educational process that will influence the achievements of the course, students, as well as the interconnectedness of self-concept and achievements of the course, students are not yet known, so the researchers are interested in taking the research with title "the Influence of training Methods and the Coordination of the Eyes and Feet Against the Smash Skill Badminton At Student POR STKIP Kusuma Negara Cijantung Jakarta Timur".

Skill badminton is a sports game that is very popular and much-loved people in Indonesia, even all over the world. This game uses a racket as a bat and shuttlecock as the object of at, can be played on a field closed and open. The game field is rectangular which is marked with lines, as well as limited by the net to separate between the areas of his own game and in-game opponents. this game is individualized, it can be played one person against one person or two people against two people. Can be played by the son, the daughter, also played by mixed couples sons and daughters.

Badminton game is exciting and relatively easy to play, because in addition to his racket is relatively light also to play it for recreation does not require the exercise too long. So many of the people who perform the game of badminton for pleasure and recreational activities. In addition, many people also love to play badminton to maintain physical fitness and health. Even today some societies badminton prepare athletes since the early to produce potential athlete and achievement in the future.

In the learning of badminton, the core learning activities of the students in the form of various activities of physical motion which are arranged in the pattern of motion to perform the various skills of badminton, through the activity of physical motion such diverse students gain experience of motion, which in turn will lead to changes in skilled behaviour that can be observed and measured as a skill.

Learning activity motion in badminton specialized mastery of a wide variety of techniques the base of the handle (grip), if the feet work (footwork), and the various kinds of blows (strokes), which consists of: punch the top of the head (overhead strokes), the punch side (sidearm strokes), and punch-punch down (underarm strokes), punch the top of the head (overhead), consisting of the lob (clear), drop shots and smash. Punch side (sidearm), consisting of the drives and drop shots. While the lower arm (underarm), consists of short service (short service), long service (long service), underhand lob, underhand drop shots and netting [3].

Among the basic techniques above, the most essential part that must be controlled by a player is the technique of the basic punches, both from above and from below. Typethe type of blow which is the most dominant used in the game of badminton, especially novice players is a blow lob (clear), punch long service (long service), and punch smash. However, all types of punches should be done by using the technique of the handle of the racket (grip) is right.

\section{A. The Basic Technique Grip the Racket (Grip).}

Badminton is known as a sport that uses much wrist. Whether or not how to hold the racket will determine the quality of the punch someone. Therefore one of the basic techniques of badminton which is very important ruled correctly by each candidate for the men's singles victory over is the grip of the racket. Master the techniques and method to grip a racket right, is an important capital to be able to play badminton well. If the technique of the handle of the racket wrong since the beginning, then it is difficult to be corrected. The handle of the racket that is the racket must be held with the use of the fingers of the hand (knuckles of the hand) with a flexible, relaxed, yet must remain powered on while hitting the shuttlecock.

\section{B. Skills Punch Smash}

Punch smash in badminton, is a form of a hard punch which is often used in the game of badminton. If it blows the other used to provoke the opponent, damaging the opponent's position or open area of the game your opponent, then punch smash aimed at ending a rally with how to hit the ball as hard as possible into the field of game opponents. no matter how perfect a person do a wide variety of blow, be vain when no equipped with a punch of smash quality.

Next Steve Baddley explained that the purpose of doing the smash skill is hitting the ball dived to the bottom with the adequate speed to be a deadly opponent with strength, so that the return of opponents to be weak. It can be obtained with speed as hitting the racket with the ball [4].

Today in the badminton game where the element of speed and power so dominate in the game, the consequences are that a player must have skills smash deadly. If we look back to the back where some of the players the legendary us who have Triumphed in the championship-international championship of features, no doubt that Rudi Hartono and Liem Swie King is as the players who pioneered the game that accentuate the elements of speed and strength to win a 
match, even today the world still commemorate the what is called the "King of Smash", a smash skill conducted by Liem Swie King may stay his prowess until at this time.

Skills smash occurs due to the presence of contraction of the basic techniques of performing the smash skill starts with pulling the right foot to the rear, the position of the left shoulder facing the opponent, weight is on the right foot, left hand raised to keep the balance.

The smash skill is one of the basic techniques in the game of badminton which is done with a powerful blow, sharp and incisive entry to the opponent's field, aims to turn off the game of the opponent as quickly in a game of badminton.

The smash skill is a skill performed from the top of the head of the result of the ball being struck lob by the opponent. This skill can be done with the forehand or backhand, but generally the smash skill is performed with the position of the forehand because with the skills of the forehand it is possible the player can perform these skills quickly and strong. In line with the statement above Kenneth R. Davidson and Lealand R. Gustavson suggested that the smash skill is a skill performed from the top of the head that allows the member an opportunity to hit swooped down at maximum speed through the top of the net [5].

Today in the badminton game where the element of speed and power so dominate in the game, the consequences are that a player must have skills smash deadly. If we look back to the back where some of the players the legendary us who have Triumphed in the championship-international championship of features, no doubt that Rudi Hartono and Liem Swie King is as the players who pioneered the game that accentuate the elements of speed and strength to win a match, even today the world still commemorate the what is called the "King of Smash", a smash skill conducted by Liem Swie King may stay his prowess until at this time. Skills smash occurs due to the presence of contraction of the basic techniques of performing the smash skill starts with pulling the right foot to the rear, the position of the left shoulder facing the opponent, weight is on the right foot, left hand raised to keep the balance.

Once a player can perform a smash skill with basic techniques that really, in the development of a player can perform a smash by means of a jump to reach the ball as high as possible. The players are outstanding, especially the players from the Asia region, they are accustomed to doing the smash skill with how to jump or commonly said to be "jumping smash". This is in line with the opinion of Reference [4] explains that in the game a high level it is possible to do a smash with a jump. Smash jump the popularized by players from the east, some of them do the smash skill while flying. By doing the smash skill while jumping would be very beneficial, because the point which hit the ball with the racket will occur is high, this will make the course of the ball is sharp and swooping, and in turn will be able to turn off the opponent's game easily.

\section{The Factors that Affect Smash Skill.}

Lutan explains, the factors that affect achievement in classified into two categories, namely internal and external factors. The purpose of the internal factors is attributes or traits that are inherent in the physical aspect and the psychic person athletes. External factors mean all the factors outside the individual whether they are in the environment where the learning, or in the more general sense [6]. The factors mentioned above strongly support the maximum achievement. This caused both of these factors to contribute to a relatively large in the achievement of sports achievements. Internal factors that are adequate would be meaningless if not supported by external factors, and vice versa. Therefore in the process of coaching athletes of external factors are all the things outside of the individual, then for an athlete to external factors can be in the form of exercises, facilities and infrastructure.

\section{Factors that Support the Smash Skill}

The characteristics of the badminton game today is the element of speed and power to beat the opponent. Speed is a physical condition that is needed by the badminton player in moving forward, backward, forward, backward, move sideways left and sideways right. While strength is a vital element which is the driving force on any physical activity. With the strength of a person can move faster, smash harder, and throw farther. Elements supporting others in doing the smash skill is the element of coordination. If the power and speed possessed by a player without the coordination of movements will be difficult to produce an explosive power that high in the perform skill, especially in the conduct of the smash skill. This is in line with what was said by Johnson and Nelson that, power is the result of force times acceleration. Strength is one component of the physical condition is very important because strength is the driving force on any physical activity.

Based on the opinion above it can be concluded that the punch speed smash badminton is the ability of that done in a short time the blow that requires the full power of the impact with the racket up with the shuttlecocks touch the floor area of the opponent's field to send the shuttlecocks to the place of the defence area of the opponent with as fast as possible both to provide pressure and to turn off the opponents in the play.

\section{METHOD}

The case experienced by students of Education High School Sports Teacher training and Education Science (POR STKIP) Kusuma Negara. STKIP Kusuma Negara is one of the private College in East Jakarta which is located in Cijantung. In the Campus there is a Department of Sport Education (POR) in the college are required to take courses in badminton. As for the design that will be used is the design of a factorial design $2 \times 3$. As for the sample in this study was obtained from the number of the reachable population, namely students who have attended courses badminton as much as 2 classes totalling 70 students.

\section{RESULTS AND DISCUSSION}

\section{A. Training Methods}

Exercise is one of the elements that can increase a person's ability in a particular thing. With exercise the ability of a can be gradually increased under the peak performance that can be achieved someone. Without doing the exercise the ability of a person can be 15 increased by itself. So also with sports, a person who wants to reach the pinnacle of achievement in the field of sports-specific course required hard work and regular practice and discipline. Exercise is a process of refinement of the sport which is regulated by 
- Add and refine strategies, techniques, tactics and patterns play

From the definition above can be explained that the refinement means improving the ability of what has been owned by an athlete to a level that is better than the previous. The principle of this pedagogical concerns how the exercise is planned, and how to maximize it, then how to teach the skills of the sport concerned which aims to improve the ability of the athlete to the pinnacle of achievement to be achieved.

Reference [7] explains that the exercise is a process of refinement of the ability to exercise that contains the material, theory and practice, using methods and rules, so that the goal can be achieved right on time [7]. Exercise is defined as a process of preparing the organism of the athlete systematically to achieve the quality of achievement of a maximum of 16 with given physical and mental load regular, targeted, increased and repetitive. Reference [8] argue that what is meant by systematic is the process of exercise is regularly conducted, well-planned, using patterns and system-specific, methodically, continuously, from simple to complex, from easy to difficult and so on [8].

Recurring intended is any motion must be trained gradually and done it many times so that the motion becomes more efficient. Refinement is the ability of what has been owned by the athletes to a better level, a scientific approach is a process of exercises using methods which really can be accounted for the truth scientifically is not happenstance or intent, and principles of education which brings the children's level of independence and maturity.

From the description of the opinion of the experts above can be concluded that exercise is a process of refinement of abilities of $\mathrm{a}$ in the branch of specific sport and take place in a period of time with attention to a variety of factors that can affect the outcome of the exercise as the exercise program that has been planned, using the scientific approach and pedagogical as well as other elements that can affect the outcome of the exercise as a method of exercise, standard exercises, the rules of the exercise in order to reach appearance standards high following the time specified to reach the pinnacle of achievement.

\section{B. The Purpose of the Exercise}

When delivering training material to the students, a coach should undoubtedly pay attention to various aspects and also supported by theories about the branch of a specific sport. This is noteworthy because the object of target practice is a human. In providing training materials a trainer should pay attention to aspects of the physical and psychic, both these aspects should be trained in a balanced manner so that need careful planning in providing training materials, then in any of the training material necessary to the preparation of the material following the goals and objectives of the exercise so that the purpose of the exercise can be achieved under the targets that have been determined previously.

Target practice in general is to improve the ability and readiness of the athlete in achieving peak performance". Target practice and the purpose of the exercise outline, among others :

- Improve the basic physical quality and general overall

- Develop and increase the potential of special physical
- Improve the quality and psychic abilities sportsmen while playing.

\section{Limitation Exercise}

It is not easy to give the most perfect about exercise. Relation to the exercise of which there need be no restrictions, the most simple that can possibly be given for exercise, "exercise is a systematic process of practice or work is done repeatedly, with increasingly adding to the number of training load or work [1].

From the description above, it can be concluded that exercise is a work process that is carried out systematically, repeated by increasing the load periodically and sustainable to improve sports performance. What is meant by systematic is planned, according to schedule, forecast and certain systems, methods from easy to more complex. Repetitive means that movement which was originally difficult to do can become easier. Automatic, and reflective of its implementation to save energy. Growing means each time a periodic and soon. Once the time came plus the burden of training.

\section{Principles of Exercise}

Principles of practice are guidelines which should be used in the exercises are well organized. These Principles refer to all aspects and tasks of the exercises, the principles that determine the style and content of the exercises, objectives, and training methods, as well as the organization [9]. Principle-the principle of the exercise itself, among others:

- The principle of loading (loading) throughout the year such exercises,

- The principle of periodization and the arrangement of the load during the circulation time of such exercise.

- The principle of the relationship between the preparation in general and specifically with the advancement of the speciality. imposition of the individual.

- The principle covers the best relationships between physical condition, technique, tactics and intellectual (ingenuity) including the will.

A coach should be meant to help in exploring and enhancing the potential possessed by athletes, either individually or in groups. The coach should also be seriously in the running exercise program, because what is planned is not always become a reality [10].

Target Practice, according to reference [11] 4 factors exercises are the most important, namely :

- Physical Factors

- Factors Engineering

- Factor Tactics

- Mental factors/psychology.

\section{E. The Method Of Practice Drill}

According to reference [12], "Tips in training techniques badminton is with the drill method. The implementation of the drill should be done while not in a state of fatigue, because in the conditions of long mastery exercises good technique will be difficult to achieve".
- The principle of individual approach and the 
Based on the understanding described above to train the engineering skills of badminton using the method of drill and practice should the current state of the athlete tired with these conditions less focus with exercise techniques which are given as a result of good technique will be difficult to achieve. The principal method of exercise drill is as follows:

- Athletes should be given deep understanding before held a particular exercise.

- The exercises are relatively brief, but must often be done.

- At the time of the exercise should be carried out the process of essential oils.

- In exercise first of all is accuracy, speed, and in the end both must be achieved as a unity.

- Exercise should have a meaning in order to behavior is extensive.

Excess drill method has the following advantages:

- Had directed retention of athletes, because all thoughts, feelings, willpower concentrated on the lesson presented in the training.

- Athletes can use the mind power well, with good teaching, then the athlete becomes more meticulous.

- The supervision, guidance and correction is immediately and directly from the coach.

- The athlete will acquire dexterity and proficiency in doing something in accordance with what he had learned.

- The coach can more easily control and be able to distinguish where the athletes are disciplined and which are not.

- The utilization of habits do not require high concentration in its implementation and can form a good habit.

- Understanding the athlete more broadly through repetitive exercises.

With the many advantages from the use of the drill method, it is expected that exercise can be beneficial for students to master the material. Exercise drill which is always under the supervision of a strict and a severe atmosphere often creates boredom for the athlete, then the coach must be smart to provide variations in running model training. The form of variations of exercises can be made a game or competition.

\section{F. The Coordination of Eye and Foot}

Coordination in principle is setting the nerves of the central and the edge one harmoniously in combining the movements of the muscles synergistic and antagonist are aligned. Coordination is the ability of a person to sequence several movements into one movement pattern effectively and efficiently. With regard to coordination, Suharno stated, "coordination is the ability of the athlete to sequence some of the motion into a motion a whole and in harmony" [13].

Based on the definition of coordination proposed by the expert can be formulated that eye-paw coordination is an integration between the eyes as the holder of the main function in this case see the situation of the game faced, and feet as the holder of the function perform a movement desired by the brain, after responding to the situation as seen by the eye. Integration involves a two-part motion, namely the eyes and feet must be linked into one pattern of movement which is good and harmonious to support the ability to perform the smash badminton.

\section{1) The factors that Affect Coordination}

The level of coordination or good and bad coordination of movement of a person is reflected in his ability to perform a movement in a smooth, precise (precise), and efficient. Someone who has good coordination not only able to perform a skill perfectly, but is also easy, fast and can do skills-new skills.

According to reference [14] stated that the "speed, strength, endurance, flexibility, kinesthetic, balance, and rhythm, provide continuity and coherence in the coordination of motion, therefore each other have a close relationship". If one element does not exist or is poorly developed, then this contributes to the perfection of coordination" [14].

Factors the nature and capabilities of the physical condition of the particular agility, flexibility, balance, strength, durability is a factor that can affect the ability of coordination that owned someone. In other words, if your agility, flexibility, balance, strength, and endurance better, then the level of coordination is also good. Thus exercise which aims to improve the components of physical condition, it will indirectly improve the ability of coordination.

2) The Role of Eye-paw Coordination to the Ability to Perform the Smash Badminton.

Coordination is one component of physical conditions that have an important role especially for sports games including the game of badminton. Almost all movement in the game of badminton requires coordination eye-foot. Many benefits are obtained if a person has good coordination. According to Suharno, utility coordination, among others can:

- coordinate some motion to be a motion that is whole and harmonious.

- efficient and useful in the use of power.

- avoid the occurrence of injury.

- $\quad$ speed up the practice, master the technique.

- enrich the tactics in the fight.

- mental readiness of the athlete is steady to the face of the game [13].

Coordination is useful to coordinate several movements into one movement which is harmonious and whole, more effectively and efficiently be issued, can avoid injury, speed up the practice to master the technique, enriching tactics in matches and improve better mental. The level of coordination that will better support his movements become more effective and efficient. But on the contrary, if the level of coordination is low, the movement is shown not effective, may even cause injury. To improve the ability to smash, then an athlete or a beginner should have good coordination. To improve the coordination to do the exercises properly.

\section{G. Description of the Data}

In this research consist of three types of variables, namely dependent variable, independent variables, and variable attributes. The dependent variable is the result of the exercise of skill smash badminton which is obtained after the student has undergone the process of exercise. The independent variable is the method of exercise drill. The variable attribute is the coordination of the student which consists of eye coordination foot high and eye coordination foot low. 
After following the exercise program with the method of exercise drill, then obtained the smash skill badminton in the form of a score (value). Eye coordination foot is intended as a variable attribute because of this variable controlled by the researcher. To determine high and low variable attributes is done by means of test coordination on the students included in the study sample.

\section{H. The Results of the Exercise Smash a Group of Students who were Taught with the Drills Drill Overall.}

From the calculation of the data collected, the results of exercise smash for the group of students who trained with the drills, the obtained score ranges between 19 to 45 , the average score of 62.06, a standard deviation of 27.45 .

- Range $(r)=47-20=27$

- A lot of classes $(\mathrm{k})=1+3,3 \log 30=6,35$ rounded up to $=6$

- Interval $=26 / 6=$ the 4.33 is rounded up to $=5$

TABLE I. DESCRIPTION OF THE DATA

\begin{tabular}{|l|l|l|}
\hline $\begin{array}{c}\text { Interval } \\
\text { Class }\end{array}$ & $\begin{array}{c}\text { Absolut } \\
\text { Frequent }\end{array}$ & $\begin{array}{c}\text { Relative } \\
\text { Frequent \% }\end{array}$ \\
\hline $18-22$ & 10 & 34.33 \\
\hline $23-27$ & 5 & 16.66 \\
\hline $28-32$ & 3 & 10 \\
\hline $33-37$ & 2 & 6.66 \\
\hline $38-42$ & 6 & 20 \\
\hline $43-47$ & 4 & 13.33 \\
\hline & 30 & $100 \%$ \\
\hline
\end{tabular}

Based on the data in the table above, the obtained $34.33 \%$ or as many as ten people obtaining a score of the results of the skills training smash badminton for the students who were trained with exercises drill above the average, $16.66 \%$ or as much as 5 people are on average, and $49.99 \%$ or as many as 15 people are below average.

\section{The Results of the Exercise Smash a Group of Students} who Have Eye Coordination Foot High that was Taught by the Method of Exercise Drill.

From the calculation data results of the exercise of the smash for the students who have eye coordination foot high who trained with the method of the exercise drill, the obtained score ranges between 32 to 45 , the average score of 40.35 , a standard deviation of 4.85 . The distribution frequency can be seen in Table 2 as follows.

- $\operatorname{Range}(\mathrm{r})=45-32=13$

- A lot of classes $(\mathrm{k})=1+3,3 \log 15=5,05$ rounded up to $=5$

- Interval $=13 / 5=2.6$ rounded up to $=3$

TABLE II. DESCRIPTION OF DATA

\begin{tabular}{|l|l|l|}
\hline $\begin{array}{c}\text { Interval } \\
\text { Class }\end{array}$ & $\begin{array}{c}\text { Absolut } \\
\text { Frequent }\end{array}$ & $\begin{array}{c}\text { Relative } \\
\text { Frequent \% }\end{array}$ \\
\hline $32-34$ & 5 & 33.33 \\
\hline $35-37$ & 0 & 0 \\
\hline $38-40$ & 2 & 6.66 \\
\hline $41-43$ & 4 & 13.33 \\
\hline $44-46$ & 4 & 13.33 \\
\hline Amount & 15 & $100 \%$ \\
\hline
\end{tabular}

Based on the data of the above table, the score obtained $26.66 \%$ or as many as eight people who obtain a score of the results of the skills training smash badminton for a group of students eye coordination foot high who trained with the method of exercise drill is above average, $6.66 \%$ or as much as two people are on average, and $33.33 \%$ or as much as five people are below average.

J. The Results of the Exercise Smash a Group of Students who Have Eye Coordination Foot Low which is Trained by the Method of Exercise Drill.

From the calculation data results of the exercise of the smash for the students who have eye coordination foot low which is trained by the method of the exercise drill, the obtained score ranges between 19 to 28 , the average score of 24.8, a standard deviation of 3.39. The distribution frequency can be seen in Table 3 as follows.

- Range $(r)=28-19=9$

- A lot of classes $(\mathrm{k})=1+3,3 \log 15=5,05$ rounded up to $=5$

- Interval $=/ 5=1.8$ rounded up to $=2$

TABLE III. DESCRIPTION OF DATA

\begin{tabular}{|l|l|l|}
\hline $\begin{array}{c}\text { Interval } \\
\text { Class }\end{array}$ & $\begin{array}{c}\text { Absolut } \\
\text { Frequent }\end{array}$ & $\begin{array}{c}\text { Relative } \\
\text { Frequent \% }\end{array}$ \\
\hline $19-20$ & 5 & 33.33 \\
\hline $21-22$ & 5 & 33.33 \\
\hline $23-24$ & 0 & 0 \\
\hline $25-26$ & 2 & 6.66 \\
\hline $27-28$ & 3 & 10 \\
\hline & 15 & $100 \%$ \\
\hline
\end{tabular}

Based on the data of the above table, the score obtained $16.66 \%$ or as much as five people who obtain a score of the results of the skills training smash badminton for a group of students eye coordination foot are low which is trained by the method of exercise drill is above average, and $0 \%$ or not some people are at average values, and $66.66 \%$ or as many as ten people are below the average while the frequency of the learning outcomes of the smash for the group of students eye coordination foot are low.

The results of the calculation test of normality of the population group in the method exercise drill students who have coordination over a foot high that was taught by the method of exercise drill, show that, with $n=15$ is obtained Lo largest $=0.090$ smaller than the $-=0.228$. This means that Ho is accepted. Means it can be concluded that the sample group of students who have eye coordination foot high by the method of the exercise drill comes from a population with normal distribution.

From the results of the calculations show that the price of F-count interaction $=-1564545.73$. The list of distribution $\mathrm{F}$ on the real level of $\alpha=0.05, \mathrm{df}=58$, obtained Ftable $=4.00$, so F-count (-1591.19) is smaller than F-table (4.00). Thus it can be concluded that there is no interaction between training methods with eye coordination foot in the process drills smash badminton. 
[4] S. Baddeley,. Go and play badminton techniques and tactics. London: Stanley Paul \& Co. Ltd,. 1992.

With the hypothesis of the influence of the above show results that are not significant, so the test continuation is not necessary. Because although the test map but still there is no significant difference between each group of exercises with the level of coordination of the eyes the legs are different, namely: (1) differences influence the results of the skills training smash badminton training methods drill for a group of students eye coordination foot high; (2) the differences influence the results of the skills training smash badminton training methods drill for a group of students eye coordination foot is low.

\section{REFERENCES}

[1] T. O. Bompa, An illustration of the interpendence between the biomotor abilities periodization of strenght. Canada: Publishing Inc. Toronto. 1994.

[2] B. Ralph, Badminton for beginners. Collorado 8011: Morton Publishing Company, 1992.

[3] S. Arisanto, Pola dasar pembinaan bulutangkis. Jakarta: PB. PBSI, 1990.

[5] R. Kenneth Davidson, Lealand R. Gustavson,. Winning badminton. New York: The Ronald Press Company, 1964.

[6] R. Lutan, Belajar keterampilan motorik, pengantar teori dan metode. Depdikbud Dirjen Dikti PPLPTK. Jakarta, 1988.

[7] S. Sukadiyanto. Pengantar teori dan metodologi melatih fisik. Yogyakarta: FIK Uiversitas Negeri Yogyakarta, 2005.

[8] D. P. Irianto. Panduan latihan kebugaran yang efektif dan aman. Yogyakarta: Lukaman Offet, 2002.

[9] Y. Yosef,. General Theory of Training. Lagos: Pan African Press, Ltd, 1982.

[10] J. Tangkudung, Penyusunan program latihan. penyelenggaraan kepelatihan olahraga pelatih pada prima koni pusat. Bandung: Ciater, 2013.

[11] J. Tangkudung. Kepelatihan olahraga, "membina prestasi olahraga". Jakarta: Cerdas Jaya, 2012.

[12] S. Kunta. Kepelatihan bulutangkis modern. Surakarta: PT Yuma Perkasa, 2010.

[13] H. P. Suharno, Metodologi pelatihan yogyakarta. Yogyakarta: IKIP, 1993.

[14] H. Harsono. Coaching dan aspek-aspek psikologi dalam coaching, Jakarta: CV Tambak Kusuma, 1998. 